\title{
Evaluation of the antibacterial and modulatory activities of ethanolic excract of Calotropis procera (Aiton) W.T. Aiton against multiresistant bacterial strains
}

Yuri Santos Geraldo', Lívia María Garcia-Leandro¹, Ana Raquel Pereira Silva², Fábia Ferreira Campina², Ana Carolina Justino de Araújo $^{2}$, Priscilla Ramos Freitas ${ }^{2}$, Antonia Thassya Lucas dos Santos ${ }^{2}$, Janaina Esmeraldo Rocha $^{2}$, Irwin Rose Alencar de Menezes² \& Henrique Douglas Melo Coutinho

1 Department of Biomedicine, Universitary Center Dr. Leão Sampaio, Juazeiro do Norte 63040-005, Brazil.

2 Department of Biological Chemistry, Regional University of Cariri, Crato 63105-000, Brazil.

Correspondence

H.D.M. Coutinho

E-mail: hdmcoutinho@gmail.com

Received: 6 November 2020

Accepted: 21 April 2021

Published on-line: 21 December 2021

\section{Resumen}

Evaluación de la actividad antibacteriana y moduladora del extracto etanólico de Calotropis procera (Aiton) W.T. Aiton contra cepas bacterianas multirresistentes

El objetivo de este estudio fue evaluar la actividad antibacteriana y moduladora del extracto etanólico de Calotropis procera (Aiton) W.T. Aiton contra cepas multirresistentes de bacterias. Por el método de microdilución, fueron definidas la concentración inhibidora mínima (MIC) del extracto y la modulación con la concentración inhibidora CIM / 8 del extracto con norfloxacina, gentamicina e imipenem contra Staphylococcus aureus, Escherichia coli y Pseudomonas aeruginosa. Se obtuvo $512 \mu \mathrm{g} / \mathrm{mL}$ para Pseudomonas aeruginosa. Se descubrió sinergismo en el caso de Staphylococcus aureus, en la modulación con norfloxacina y gentamicina, mientras que con imipenem frente a Pseudomonas aeruginosa y con gentamicina para Escherichia coli. Con base en estos resultados, se necesitan más estudios para probar la actividad antibacteriana del extracto.

Palabras clave: Modulación; Calotropis procera; Resistencia.

\begin{abstract}
The objective of this study was to evaluate the antibacterial and modulatory activities of ethanolic extract of Calotropis procera (Aiton) W.T. Aiton against resistant species. By microdilution method, the minimum inhibitory concentration (MIC) of the extract and modulation of the subinhibitory concentration $\mathrm{MIC} / 8$ to norfloxacine, gentamicin and imipenem against Staphylococcus aureus, Escherichia coli and Pseudomonas aeruginosa. There was obtained $512 \mu \mathrm{g} / \mathrm{mL}$ to Pseudomonas aeruginosa. To Staphylococcus aureus, modulation showed synergism to norfloxacin and gentamicin, with imipenem against Pseudomonas aeruginosa and gentamicin against Escherichia coli. Based on these results, more studies are needed to test the antibacterial activity of the extract.
\end{abstract}

Key words: Modulation; Calotropis procera; Resistance. 


\section{Introduction}

Calotropis procera (Aiton) W.T. Aiton (Apocinaceae) is a shrub, popularly known as "jealous" or "bag of old". This plant is widely available in brazilian territory, mainly in the northeast region, but is not native, the plant came from Africa, probably brought in caravels in the form of seeds and found an environment conducive to its development since both regions have similar climates. Its organs have several utilities, highlighting its therapeutic functions as hepatoprotection and antiinflammatory (Fabricante et al. 2013, Quazi et al. 2013).

Bacteria are cosmopolitan, inhabiting soil, water, food, hospitals, colonizing the skin and other organs to survive. Through a natural mechanism of adaptation and persistence of the species, the bacteria are able to resist forms of controlling their growth, making, for example, several antibiotics incapable of acting effectively on them. This may happen through the unrestrained use of antibiotics to cure infections, since they can initiate processes of conjugation, transduction and transformation, in order to guarantee this characteristic (Santos 2004).

The ability of bacteria to develop resistance to antibiotics is worrying, since many of them are potential agents causing serious diseases, such as Staphylococcus aureus Rosenbach and Escherichia coli (Escherich,). It is noticed that of the bacteria that cause hospital infection, about $70 \%$ are resistant to the antibiotics of choice, requiring the use of more powerful drugs, which are necessarily more expensive and toxic to the human organism (Oliveira \& Silva 2009).

To avoid the use of even more aggressive drugs to the patient being treated, several methods are arranged that avoid the resistance of the bacteria. The antibiotic modulation technique, which is developed by combining a plant extract with a given antibiotic to increase its therapeutic potential is a great alternative, it has a low cost and high efficiency, simple to reproduce and because it is a natural component added to the drug in low concentrations, its undesirable effects are minimal (Tintino et al. 2013).

The domestic use of medicinal plants for the purpose of curing or controlling health illnesses is very intrinsic to the Brazilian population. This research was developed to verify the antibacterial and modulatory potentials of the plant $C$. procera against some of species of bacteria that most developed resistance to the antibiotics tested, intending to be an alternative of control of the resistance or aid in antibiotic therapy, since this plant already has proven phytotherapeutic effects (Tomazzoni et al. 2006).

\section{Materials and methods}

\section{Botanical extract and Bacterial samples}

The ethanolic extract from the leaves of C. procera (EELCP) was donated by Professor Micheline de Azevedo Lima, from the Federal University of Paraíba - UFPB. The microorganisms used in the tests were obtained from the Laboratory of Microbiology and Molecular Biology of the Regional University of Cariri (URCA), in which resistant species of Escherichia coli (EC06), Staphylococcus aureus (SA10) and Pseudomonas aeruginosa Schroeter (PA15) were selected.

\section{Minimum Inhibitory Concentration (MIC) Determination}

The antibacterial activity was defined by the minimum inhibitory concentration (MIC) of the EELCP, by the microdilution method in $10 \% \mathrm{BHI}$, in triplicate and combined with the sterility control, where the ethanolic extract $(1024 \mu \mathrm{g} / \mathrm{mL})$ was associated with the inoculum of each bacteria in a 96-well microdilution plate, and made at serial 1:1 dilution of the extract, to visualize the growth or absence of growth when added a chromogen (Resazurin) indicator, sensitive to $\mathrm{pH}$ change produced by bacterial growth, indicating in which concentration the extract is effective (CLSI 2012, Coutinho et al. 2008a, Coutinho et al. 2008b, Javadpour et al. 1996).

\section{Modulation of antibacterial activity}

To verify the modulatory activity of EELCP, it was used some drugs considered standards in the treatment of infections by the tested bacteria: norfloxacin, imipenem and gentamicin. Antibiotics were prepared in solvent dimethylsulfoxide (DMSO) based on the recommendations contained in the Clinical Laboratory Standards Institute of 2012 (CLSI 2012).

The modulation of antibacterial activity was done by the serial 1:1 microdilution method of the 
antibiotic in $10 \% \mathrm{BHI}$, in triplicate and combined with the sterility control, in the absence and presence of the EELCP in subinhibitory concentration equivalent to $1 / 8$ of the MIC that was previously established, in order to verify the synergistic or antagonistic modulation for each antibiotic in relation to each bacteria, and to compare the columns it contains with those that do not contain the extract (Matias et al. 2013).

\section{Statistical Analysis}

The tests were performed in triplicate and the results were shown in geometric mean, using the double-way ANOVA method with post-test Bonferroni using GraphPadPrism 6.0 software (level of significance: $p<0.05$ ).

\section{Results}

After performing the Minimum Inhibitory Concentration (MIC) test against resistant bacteria, the results were defined: for $P$. aeruginosa the MIC was $512 \mu \mathrm{g} / \mathrm{mL}$, and $\geq 1024 \mu \mathrm{g} / \mathrm{mL}$ for $S$. aureus and $E$. coli, thus the results were found not to be clinically relevant.

When analyzing the MIC of the extract with MIC of each antibiotic for each bacteria tested (Fig. 1), it was possible to see that only in $P$. aeruginosa the extract presented a reduced MIC when compared to the MIC of norfloxacin. In other relations, the extract always needs a higher concentration when compared to the tested antibi- otics, revealing the greater sensibility of the bacteria to the antibiotic functions of the extract. EELCP showed a significant modulatory effect on, at least, one antibiotic for each bacterial species.

Comparing the columns of the association of the extract and antibiotics with those of their respective controls (Fig. 2), it was obtained: for $S$. aureus, norfloxacin showed synergistic effect, whose MIC of the antibiotic was reduced by $37 \%$. On the other hand, imipenem had its MIC increased for the same bacteria, an increase of more than $400 \%$. gentamicin had a synergistic effect on modulation, reducing MIC by $65 \%$.

For $P$. aeruginosa, the extract had the most important significance through synergism with imipenem, producing a reduction of the antibiotic MIC of $99.952 \%$. In E. coli, the extract reduced MIC of gentamicin, with a decrease of $37.4 \%$ in concentration, characterizing the activity as synergistic.

It is noteworthy that the extract of the plant has a relevant modulatory function, and may be synergistic or antagonistic to the same bacteria with different antibiotics, such as $S$. aureus, when under the same conditions, the extract enhanced the efficiency of norfloxacin and gentamicin; did not have the same effect in association with imipenem. However, when it comes to P. aeruginosa, the extract had the best synergistic effect with the same imipenem, showing that the applicability situations of the technique can have

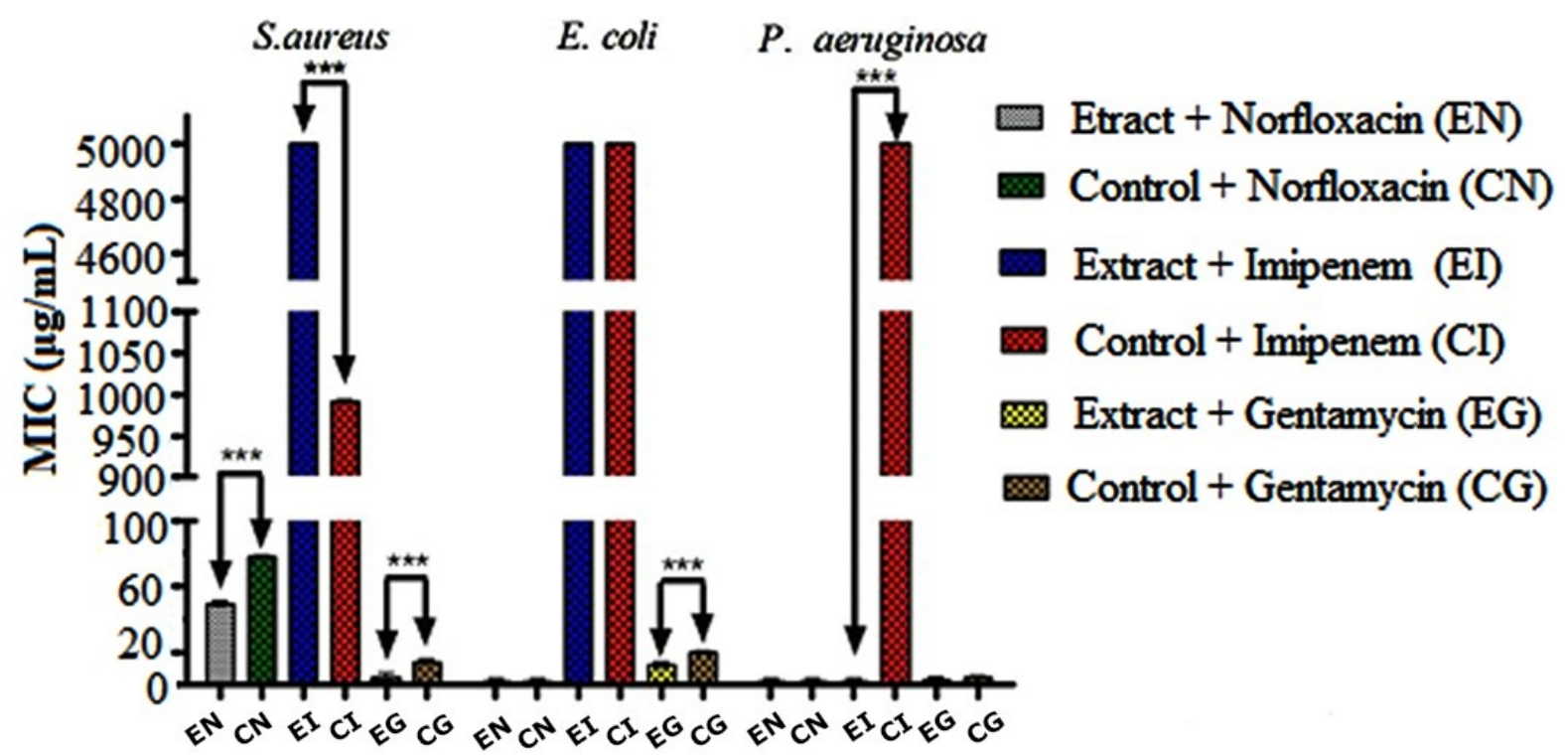

Figura 1. Evaluación del potencial antibacteriano de EELCP. (nivel de significación: p: $<0,05$ ).

Figure 1. Evaluation of the antibacterial potential of EELCP. (level of significance: $p<0.05$ ). 


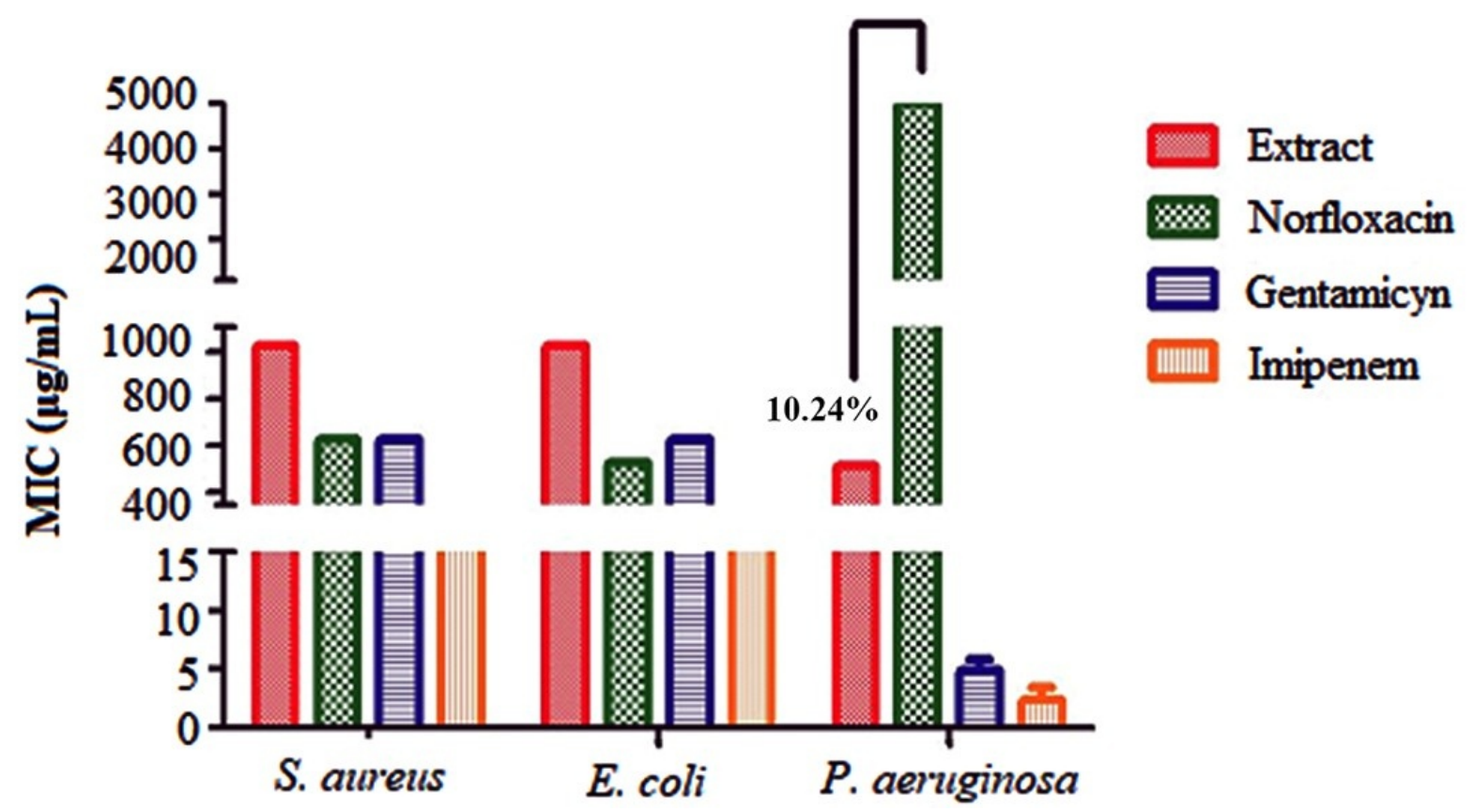

Figura 2. Potencial modulador de EELCP sobre el efecto antibacteriano de los antibióticos contra especies resistentes a múltiples fármacos (nivel de significación: p: <0,05).

Figure 2. EELCP modulator potential on the antibacterial effect of antibiotics against multidrug resistant species (level of significance: $p$ $<0.05)$.

diverse results.

\section{Discussion}

A study that deals with fractions of $C$. procera and its antibacterial effects shows that these fractions are more effective against $P$. aeruginosa, reporting that the parts most eager for the bacteria are polar, a result consistent with the one found in this research. Like the study realized with the species $C$. procera showed antibacterial activity against strains of $P$. aeruginosa, using the disk diffusion method (Bilal et al. 2020, Brito et al. 2010).

When it comes to $E$. coli, the synergistic effect with gentamicin is observed, being similar to the analysis of fractions of the plant Lygodium venustum SW, which produced a drastic reduction of MIC of gentamicin by the dichloromethane fraction against the strains of this bacteria. Although they are different plants, the study helps support the idea that the extract of $C$. procera has modulator of antibiotics effect (Morais-Braga et al. 2013).

The tested plant has already been used in other studies, which showed therapeutic effects, highlighting the hepatoprotective, antifungal and antiinflammatory, as well as general toxic effects (Costa et al. 2015).
Several evaluations of antibiotic activities from plants also showed effective results, such as Aloysia gratissima (Gillies \& Hook). Tronc. and Ocimum gratissimum L., whose essential oils produced antibacterial effect against species of Gram positive bacteria, whereas for $O$. gratissimum, this effect is probably caused by the component eugenol, which comprises $57 \%$ of the plant. Although it is from essential oil, the result described helps to emphasize the modulating activity of the plant under study (Franco 2007).

Although the plant is different, another study that has similar methodology treats that the $O$. gratissimum oil generates an antagonistic effect in the modulation of aminoglycoside antibiotics against strains of $S$. aureus, corroborating with the results obtained (Aguiar et al. 2015).

\section{Conclusions}

The MIC of the EELCP did not present clinically relevant activity for the species of $S$. aureus and E. coli. On the other hand, when evaluated against the strain of $P$. aeruginosa, it presented a clinically relevant effect with a MIC of $512 \mu \mathrm{g} / \mathrm{mL}$. The EELCP also demonstrated a significant modulatory effect in at least one antibiotic for each bacterial species; for $S$. aureus strains it showed synergistic results with norfloxacin and genta- 
micin, and antagonism with imipenem; for $P$. aeruginosa had synergism with imipenem, and antagonism to gentamicin and norfloxacin; E. coli obtained synergism with gentamicin and antagonism with norfloxacin and imipenem. Bacterial resistance is a universal problem and must be inhibited. To this end, the modulation of antibiotic activity is arranged, but needs to be studied, since its results may be diverse.

\section{References}

Aguiar JJ, Sousa CP, Araruna MK, Silva MKN, Portelo AC, Lopes JC, . . Matias EFF. 2015. Antibacterial and modifying-antibiotic activities of the essential oils of Ocimum gratissimum L. and Plectranthus amboinicus L. European Journal of Integrative Medicine 7:151-156. https://doi.org/10.1016/j.eujim.2014.10. $\underline{005}$

Brito SA, Coutinho HDM, Barros ARC, Rodrigues, FFG \& Costa JGM. 2010. Prospecção fitoquímica e avaliação da atividade antibacteriana e toxicidade do látex de Calotropis procera (Asclepidaceae). Cadernos de Cultura e Ciências URCA 2: 31-39.

CLSI - Clinical and Laboratory Standards Institute. 2012. Methods for dilution antimicrobial susceptibility tests for bacteria that grow aerobically; Approved standard - Ninth edition. Wayne, PA: NIH.

Costa NDJ, Oliveira SFC, Silva JN, Pacheco ACL, Abreu MC, Cavalcante AAC, . . . Ferreira PMP. 2015. Potencial terapêutico e tecnológico da planta Calotropis procera. Revista Geintec, gestão, inovação e tecnologias 5:2222-2236. https://doi.org/ 10.7198/geintec.v5i3.434

Coutinho HDM, Costa JGM, Lima EO, Falcão-Silva VS \& Siqueira-Júnior JP. 2008a. Enhancement of the antibiotic activity against a multiresistant Escherichia coli by Mentha arvensis L. and chlorpromazine. Chemotherapy 54: 328-330. https://doi.org/10.1159/ $\underline{000151267}$

Coutinho HDM, Costa JGM, Siqueira-Júnior JP \& Lima EO. 2008b. In vitro anti-staphylococcal activity of Hyptis martiusii Benth against methicillin-resistant Staphylococcus aureus: MRSA strains. Revista Brasileira de Farmacognosia 18: 670-675. https://doi.org/10.1590/S0102-695X2008000500005

Fabricante JR, Oliveira MNA \& Siqueira-Filho JÁ. 2013. Aspectos da ecologia de Calotropis procera
(Apocynaceae) em uma área de Caatinga alterada pelas obras do Projeto de Integração do Rio São Francisco em Mauriti, CE. Rodriguésia 64: 647-654. https://doi.org/10.1590/S2175-78602013000300015

Franco AL. 2007. Avaliação da composição química e atividade antibacteriana dos óleos essenciais de Aloysia gratissima (Gillies\&Hook) Tronc. (alfazema), Ocimum gratissimum L.(alfavaca-cravo) e Curcuma longa L.(açafrão). Revista Eletrônica de Farmácia 4: 208-220. https://doi.org/10.5216/ref.v4i2.3063

Javadpour MM, Juban MM, Lo WCJ, Bishop SM, Alberty JB, Cowell SM, . . . McLaughlin ML. 1996. De novo antimicrobial peptides with low mammalian cell toxicity. Journal of Medicinal Chemistry 39: 3107-3113. https://doi.org/10.1021/jm9509410

Matias EFF, Alves EF, Santos BS, Sobral-Souza, CE, Alencar-Ferreira JV, Lavor AKLS, . . Costa JGM. 2013. Biological activities and chemical characterization of Cordia verbenacea DC. As tool to validate the ethnobiological usage. Evidence-Based Complementary and Alternative Medicine 1-7. https://doi. org/10.1155/2013/164215

Morais-Braga MFB, Souza TM, Santos KKA, Guedes GMM, Andrade JC, Tintino SR, . . Coutinho HDM. 2013. Atividade antibacteriana, antifúngica e moduladora da atividade antimicrobiana de frações obtidas de Lygodium venustum SW. Boletin Latinoamericano y del Caribe sobre Plantas Medicinales y Aromaticas 12: 38-43.

Oliveira AC \& Silva RS. 2009. Desafios do cuidar em saúde frente à resistência bacteriana: uma revisão. Revista Eletronica de Enfermagem, 10:189-197. https://doi.org/10.5216/ree.v10i1.8011

Quazi S, Mathur K \& Arora S. 2013. Calotropis procera: An overview of its phytochemistry and pharmacology. Indian Journal of Drugs, 1: 63-9.

Santos NQ. 2004. A resistência bacteriana no contexto da infecção hospitalar. Texto e contexto enfermagem 13: 64-70. https://doi.org/10.1590/S01 04-07072004000500007

Tintino SR, Cunha FAB, Santos KKA, Guedes GMM, Souza CES, Matias EFF . . . Coutinho HDM. 2013. Atividade moduladora de extratos etanólico e hexânico de raiz de Costus cf. arabicus sobre drogas antimicrobianas. Revista Brasileira de Biociências 11: 157-162.

Tomazzoni MI, Negrelle RRB \& Centa MDL. 2006. Fitoterapia popular: A busca instrumental enquanto prática terapêuta. Texto e Contexto Enfermagem 15: 115-121. https://doi.org/10.1590/S0104-070720060 $\underline{00100014}$ 